\title{
Sediment and trace element depositional history from the Ajkwa River estuarine mangroves of Irian Jaya (West Papua), Indonesia
}

\author{
Gregg J. Brunskill ${ }^{\mathrm{a}, *}$, Irena Zagorskis ${ }^{\mathrm{a}}$, John Pfitzner $^{\mathrm{a}}$, Joanna Ellison ${ }^{\mathrm{b}}$ \\ a Australian Institute of Marine Science, PMB 3, Townsville, Queensland 4810, Australia \\ ${ }^{\mathrm{b}}$ School of Geography and Environmental Studies, University of Tasmania, Locked Bag 1376, Launceston, Tasmania 7250, Australia
}

Available online 6 October 2004

\begin{abstract}
Radiotracer ${ }^{210} \mathrm{~Pb}$ and contaminant copper were used to estimate sediment accumulation rates in 4 cores from the Ajkwa River estuary and mangrove tidal channels in western Irian Jaya. Mass accumulation rates

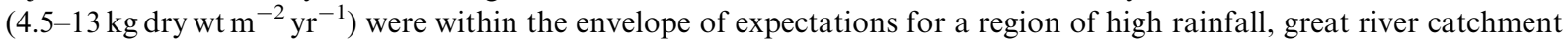
relief, and rapid tectonic uplift of mountains. Copper accumulation rates were enhanced 40 fold in surface sediments, compared to pre-1950 sections of the sediment cores. These recent sediments with enhanced copper concentrations come from Freeport Indonesia mine tailings over the last 27 years. Variations in sediment core profiles of $\mathrm{Al}, \mathrm{Fe}$, and organic carbon were small, indicating no great change in bulk sediment composition. Sulfur concentrations decline toward the sediment surface, suggesting a decline in rates of microbial sulfate reduction. Enhanced sediment copper concentrations will be a useful tracer of sediment dispersal from the Ajkwa River estuary along this coast.
\end{abstract}

(C) 2004 Elsevier Ltd. All rights reserved.

Keywords: Irian Jaya; Ajkwa River estuary; Mangrove sedimentation rates; Trace elements; $\left(4^{\circ}-5^{\circ} \mathrm{S} ; 136^{\circ}-137^{\circ} \mathrm{E}\right)$

\section{Introduction}

This study investigates recent sedimentation trends in the Ajkwa estuary, located downstream of the P.T. Freeport Indonesia (PTFI) Contract of

\footnotetext{
*Corresponding author. Tel.: +61-7-4753-4444; fax: +61-74772-5852

E-mail address: g.brunskill@aims.gov.au (G.J. Brunskill).
}

Work mining operation. The copper-gold mine is located some $3700 \mathrm{~m}$ above sea-level in the Jayawijaya Mountains of Irian Jaya, Indonesia (Fig. 1(a)), and has been operating since 1972 (Mealey, 1996). Mine tailings are now discharged into the Ajkwa River at a present rate of about 125,000 tonne per day. The copper-rich tailings consist of sand and smaller sized particles of ground rock. The river rapidly descends in 


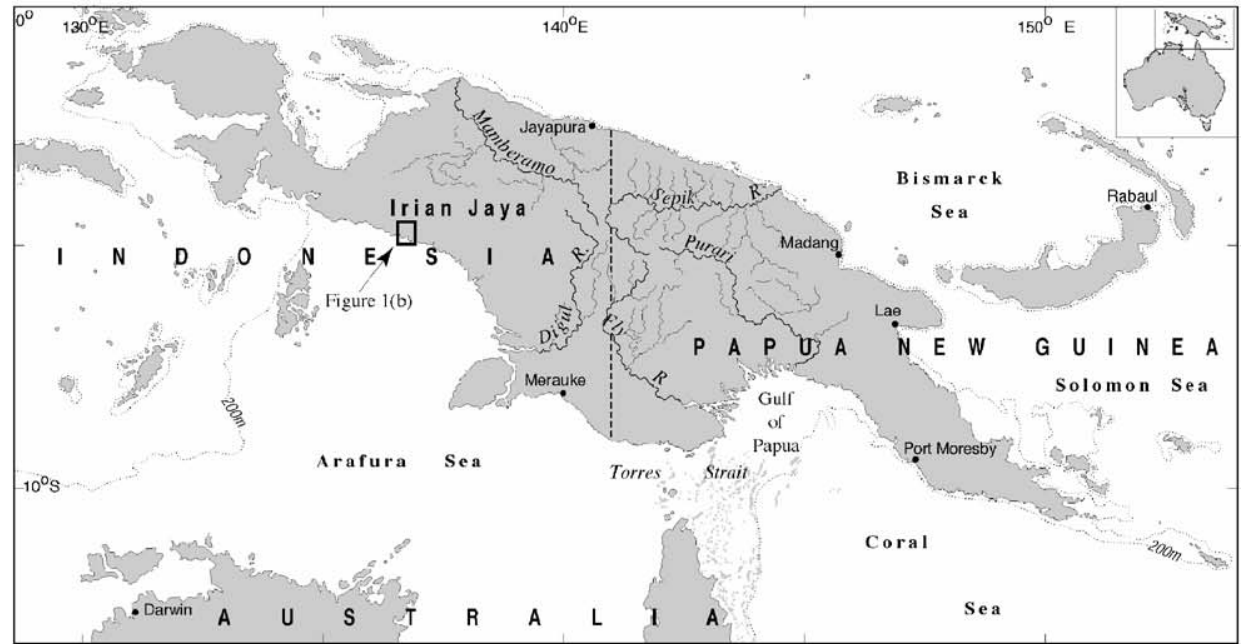

(a)

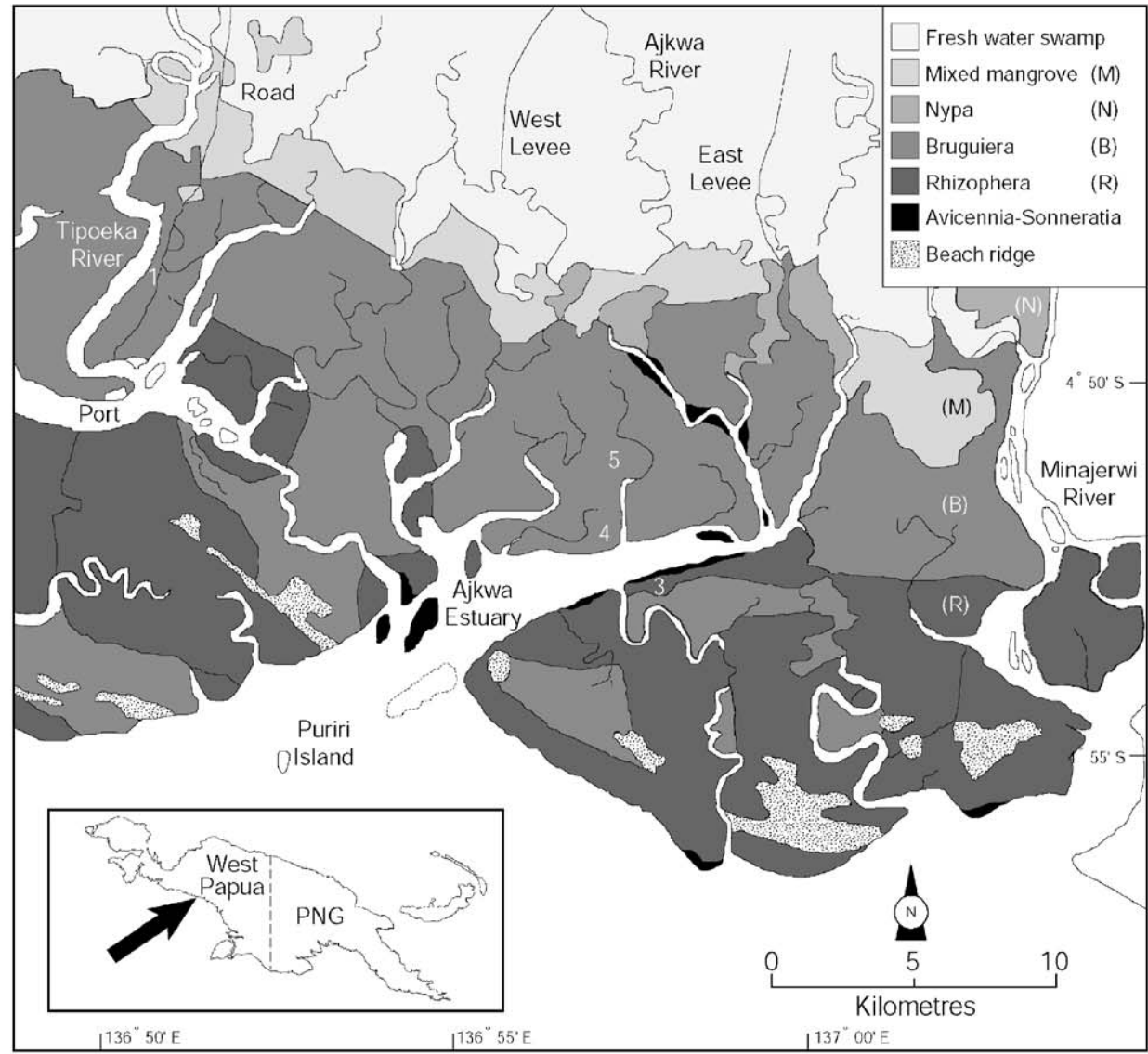

(b)

Fig. 1. (a) Map of New Guinea, indicating the location of the Ajkwa River estuary, the Torres Strait and the Gulf of Papua. (b) Detailed map of sediment core location sites within the Ajkwa River estuary, the Ajkwa estuary main channel, and the levees on the freshwater channel of the Ajkwa River. Also indicated are the general mangrove community types in this estuary. 
elevation to the lowland flood plains, where river transported tailings and natural sediment settle in the $130 \mathrm{~km}^{2}$ Ajkwa deposition area (ADA), contained by levees on the eastern and western margins (Fig. 1(b)). South of the ADA is some $200 \mathrm{~km}^{2}$ of estuarine mangrove forest, receiving tidal exchange from the Arafura Sea.

Five major mangrove communities of the Ajkwa River estuary are shown in Fig. 1(b). The most extensive is Bruguiera dominated forest, of Bruguiera cylindrica, B. parviflora, Rhizophora apiculata, $R$. mucronata, and Xylocarpus mekongensis, mainly north of the main Ajkwa estuary mouth. In lower salinity areas upriver, Nypa fruticans and mixed mangrove/ floodplain freshwater swamp forest occur. At higher salinities, particularly south of the estuary mouth, Rhizophora dominated forest occurs, with $R$. stylosa, B. gymnorrhiza, $R$. apiculata and $R$. mucronata commonly occurring. In all salinities of the mangrove area, pioneer communities of Avicennia marina, A. officinalis, A. eucalyptifolia and Sonneratia caseolaris occur on accreting banks. Climate is humid wet tropical with no dry season, and forest stature is large. In the Bruguiera and Rhizophora communities, tree size reaches $25-30 \mathrm{~m}$ in height.

The purpose of this study was to determine century scale sediment and trace metal deposition history in sediment cores from the estuary of the Ajkwa River. This is being done to assess the influence of mine tailings dispersal in the region, and to provide information for future sediment dispersal studies. On a broader scale, this work can be viewed as the beginning of a research program to follow a multidecadal coastal spike experiment, with excess sedimentary copper being a tracer for the input from one river to the inner shelf of the Arafura Sea. This coastal region of western New Guinea (Fig. 1(a)) receives relatively large inputs of natural sediment from dozens of rivers that drain the high mountain ranges, where erosion and transport rates of sediment are very high (Milliman, 1995). It seems likely that most of the riverine sediment is trapped in the low relief floodplains, estuaries, and inner shelf of the Arafura Sea, in accordance with models proposed by Project TROPICS (see http://www.aims. gov.au/tropics).

\section{Methods}

Sediment core locations are shown in Fig. 1(b). Site 1 was selected in the Tipoeka River estuary as a control, located to the west of the PTFI road to the Amamapere Port, and is not in the direct path of tailings discharge from the Ajkwa River. Site 1 was in Bruguiera/Xylocarpus forest. Sites 3-5 were located in a north-south transect across the tidal mangrove swamps directly seaward of the ADA. Sites 5 and 4 were in Bruguiera/Xylocarpus forest north of the Ajkwa mouth, and site 3 was in Rhizophora forest south of the Ajkwa mouth. All core sites were located within the mangrove forest, around $20 \mathrm{~m}$ from the edge of the tidal creek.

Sediment cores were obtained in July 1997 with $10 \mathrm{~cm}$ internal diameter PVC core tubes, and were sliced in the field with clean steel and plastic tools to $4 \mathrm{~cm}$ intervals. Samples were stored in plastic sacks, and kept frozen throughout storage and transport. Longer cores were obtained at each site for reconstruction of long-term vegetation change using palynology and ${ }^{14} \mathrm{C}$ dating, to be reported elsewhere.

Gamma spectrometric measurements of ${ }^{210} \mathrm{~Pb}$, ${ }^{226} \mathrm{Ra},{ }^{137} \mathrm{Cs}$, and other isotopes were made on $50-150 \mathrm{~g}$ of dried and ground bulk sediment packed (with a 10 ton hydraulic press) into a custom designed radon-tight plastic container. After storage for 3-4 weeks, the radon daughter in-growth allows direct estimation of ${ }^{226} \mathrm{Ra}$ from its photopeak at $186.0 \mathrm{keV}$ and from the suite of ${ }^{214} \mathrm{~Pb}$ at 295.2 and $351.9 \mathrm{keV}$, and ${ }^{214} \mathrm{Bi}$ at $609 \mathrm{keV}$. ${ }^{210} \mathrm{~Pb}$ was estimated from its $46.5 \mathrm{keV}$ gamma emission. Thermonuclear bomb fallout nuclide ${ }^{137} \mathrm{Cs}$ was estimated from the $661.6 \mathrm{keV}$ gamma emission of ${ }^{137 m}$ Ba. ${ }^{238} \mathrm{U}$ activity was estimated from ${ }^{234} \mathrm{Th}$ activity after several months of equilibration time. Four planar germanium detectors were used inside $10 \mathrm{~cm}$ thick lead-walled castles with steel liners. The energy spectra of the gamma spectrometers were calibrated with Amersham and CANMET standards of known activity spikes of suitable nuclides mixed into very low-activity silica sand of geometry and mass identical to the sediment samples to produce secondary standards. IAEA-315 Marine Sediment Reference Material is regularly counted 
as a quality assurance procedure to ensure that the calibration of all detectors is maintained within range of the certified reference values. Counting errors of the samples were less than $10 \%$, except for some very low activity ${ }^{137} \mathrm{Cs}$ and ${ }^{210} \mathrm{~Pb}$ samples, which had errors of $30 \%$. We are confident that our independent calibrations for ${ }^{226} \mathrm{Ra}$ and ${ }^{210} \mathrm{~Pb}$ allow good estimation of excess ${ }^{210} \mathrm{~Pb}$, as deep sediment core slices from the Gulf of Papua and north Queensland coastal embayments are at equilibrium $\left({ }^{226} \mathrm{Ra}={ }^{210} \mathrm{~Pb}\right)$, within the error of measurement.

Interpretations of the radiochemical tracers of sedimentation history were done with several submodels described by Robbins (1978, 1986), which utilize a ${ }^{210} \mathrm{~Pb}$ mixed layer thickness, a decadal-century scale average input of ${ }^{210} \mathrm{~Pb}$ from atmospheric fallout, measurements of thermonuclear bomb fallout ${ }^{90} \mathrm{Sr}\left({ }^{137} \mathrm{Cs}\right)$ over $1950-1975$ in Darwin and Townsville (Moroney, 1979), and diffusion coefficients for ${ }^{210} \mathrm{~Pb}$ and ${ }^{137} \mathrm{Cs}$ in marine sediments ( $\mathrm{Li}$ and Gregory, 1974). We have determined estimates of atmospheric flux of ${ }^{210} \mathrm{~Pb}$ and ${ }^{137} \mathrm{Cs}$ from north Queensland rain collections and 15 soil profiles $\left(50 \mathrm{~Bq}^{210} \mathrm{~Pb} \mathrm{~m}^{-2} \mathrm{yr}^{-1}\right.$, $326 \pm 104 \mathrm{~Bq}^{137} \mathrm{Cs} \mathrm{m}^{-2}$ ). Data from Moroney (1979) suggests a Darwin inventory of $292 \pm$ $60 \mathrm{~Bq}^{137} \mathrm{Cs} \mathrm{m}^{-2}$, decay adjusted to 2000 . Wasson (1992) estimated an inventory of $247 \pm$ $28 \mathrm{~Bq}^{137} \mathrm{Cs} \mathrm{m}^{-2}$ for the Magela Creek floodplain east of Darwin, decay adjusted to 2000. Bonnyman and Molina-Ramos (1971) gave an average ${ }^{210} \mathrm{~Pb}$ atmospheric flux for Darwin as $90 \mathrm{~Bq} \mathrm{~m}^{-2} \mathrm{yr}^{-1}$. We determined three soil profiles of excess ${ }^{210} \mathrm{~Pb}$ in a high intertidal mangrove peat on Sassie Island in Torres Strait, yielding flux estimates of $18-22 \mathrm{~Bq} \mathrm{~m}^{-2} \mathrm{yr}^{-1}$. From this range of $18-90 \mathrm{~Bq} \mathrm{~m}^{-2} \mathrm{yr}^{-1}$, we select $50 \mathrm{~Bq}^{210} \mathrm{~Pb} \mathrm{~m}^{-2} \mathrm{yr}^{-1}$ as our best estimate of average annual atmospheric input to the sediment surface at our study sites.

Log excess ${ }^{210} \mathrm{~Pb}$ activity for each core slice is plotted against accumulated dry weight per unit area, to correct for compaction and variations in water content. Excess ${ }^{210} \mathrm{~Pb}=$ Total ${ }^{210} \mathrm{~Pb}^{226} \mathrm{Ra}$. Mass accumulation rate (MAR) is determined from the regression line on excess ${ }^{210} \mathrm{~Pb}$ activity versus accumulated dry sediment weight per unit area, with attempts to account for the effects of surface sediment mixing on the slope of this regression line. The sedimentation tracer model gives more weight to the surface sediment activities of high excess ${ }^{210} \mathrm{~Pb}$, and less weight to the deeper core excess ${ }^{210} \mathrm{~Pb}$ data, where the uncertainty is larger. In these cores, the activity of ${ }^{137} \mathrm{Cs}$ is very low and often not detectable, which is of little value for estimation of MAR. Where the excess ${ }^{210} \mathrm{~Pb}$ profile allows a useful interpretation of MAR, we also include an insert graph showing the linear relation of excess ${ }^{210} \mathrm{~Pb}$ to accumulated dry sediment weight, to show that the deeper core slices have no excess ${ }^{210} \mathrm{~Pb}$ (an exception at site 3 is explained in the results). We also consider the known history of copper mine tailings supply to this region as an additional tracer of depositional history, and some historical information on milling rate, ore and overburden production from PTFI is given in Mealey (1996) and Fig. 2. Readers who wish to see tables of numerical data for core ${ }^{226} \mathrm{Ra},{ }^{210} \mathrm{~Pb}$, and ${ }^{137} \mathrm{Cs}$ may request this from our email address.

Samples for elemental measurements were freeze-dried and homogenized by grinding. Organic carbon (OC) was determined by acidification, combustion, and infra-red detection on a Shimadzu TOC-5000 Total Organic Carbon Analyzer. Total carbon (carbonate plus organic carbon) and nitrogen $(\mathrm{N})$ were determined by gas chromatography on a Perkin Elmer 2400 CHNS/O Series II Analyzer. Aluminium (Al), iron (Fe), sulfur $(\mathrm{S})$, and copper $(\mathrm{Cu})$ were determined by inductively coupled plasma atomic emission spectroscopy (ICP-AES, Varian Liberty 220) after nitric and perchloric acid digestion of the sediment sample (Loring and Rantala, 1992). Lead ( $\mathrm{Pb}$ ) and cadmium $(\mathrm{Cd})$ were determined by Zeeman graphite furnace atomic absorption spectroscopy (ZGF-AAS) on a similar digestion. Precision of $\mathrm{Cd}$ analytical measurement was estimated to be $\pm 179 \mathrm{pmol} \mathrm{Cdg}^{-1}$. Mercury $(\mathrm{Hg})$ was determined by cold vapor ICP-AES (Walker et al., 1996), with a replication error estimate of \pm 150 pmol $\mathrm{Hgg}^{-1}$. These ICP-AES and ZGF-AAS measurements represent strong acid extracts of the bulk sediment, and do not include elements contained in acid resistant minerals (quartz, heavy minerals). Analytical precision was $5 \%$ for $\mathrm{N}$ and 

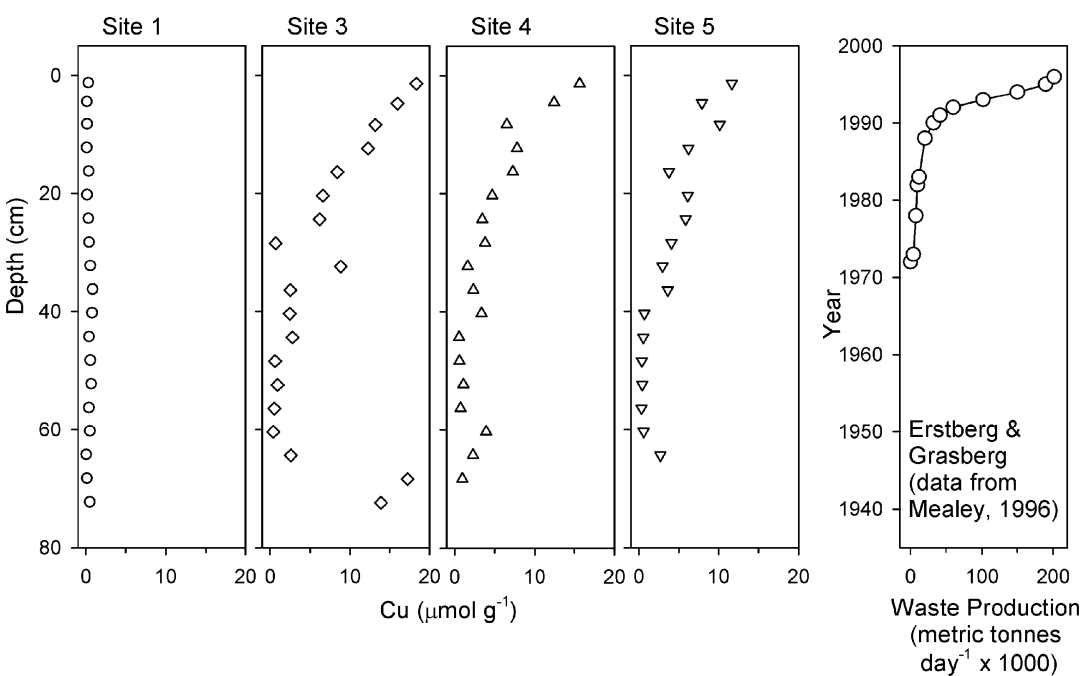

Fig. 2. Variation of sediment concentration of copper $(\mathrm{Cu})$ in cores collected at sites $1,3,4$ and 5 from the Ajkwa River estuary. The fifth panel shows the history of waste production of the Ertsberg and Grasberg phases of the copper and gold mine in the headwaters of the Ajkwa River (Mealey, 1996). The bottom of the sediment core from site 3 was deposited in 1940 (see Fig. 4, site 3), and is contemporaneous with this mine waste production history.

Table 1

Locations of Hiller sediment core sites, vegetation, and characterization of the bulk sediment from the Ajkwa River estuary

\begin{tabular}{llllll}
\hline Site & Latitude & Longitude & Vegetation & Munsell color & Sediment type \\
\hline 1 & $4^{\circ} 47.72^{\prime} \mathrm{S}$ & $136^{\circ} 50.90^{\prime} \mathrm{E}$ & Bruguiera & $10 \mathrm{YR} 3 / 1$ dark grey & organic silty clay to $100 \mathrm{~cm}$ \\
3 & $4^{\circ} 52.41^{\prime} \mathrm{S}$ & $136^{\circ} 58.49^{\prime} \mathrm{E}$ & Rhizophora & $10 \mathrm{YR} 3 / 1$ & organic silty clay \\
4 & $4^{\circ} 51.46^{\prime} \mathrm{S}$ & $136^{\circ} 57.40^{\prime} \mathrm{E}$ & Bruguiera & $5 \mathrm{Y} 3 / 1$ very dark grey & hard silty clay, organic poor \\
5 & $4^{\circ} 50.24^{\prime} \mathrm{S}$ & $136^{\circ} 57.94^{\prime} \mathrm{E}$ & Bruguiera, & $10 \mathrm{YR} 3 / 11$ dark grey & organic silty clay to $195 \mathrm{~cm}$ \\
& & & Xylocarpus Avicennia, & &
\end{tabular}

$3 \%$ for all other elements. All the elemental determinations are calculated on dry weights.

\section{Results}

A map of the Ajkwa River estuary core sites is given in Fig. 1(b), and the locations and character of each site is given in Table 1.

\subsection{Site 1}

The core from site 1 was obtained from the margin of a tidal creek within the Jaramaya (Tipoeka) River channel, about $100 \mathrm{~m}$ west of the PTFI road, $20 \mathrm{~m}$ within the mangrove forest, and is furthest away from the influence of the mine tailings pathway through the Ajkwa River estuary. This is the location of the PTFI Permanent Plot 1 for long term biodiversity monitoring. The core log (Table 1) indicates a homogeneous organic, very dark grey silty clay to $100 \mathrm{~cm}$ depth, and the ${ }^{210} \mathrm{~Pb}$ profile (Fig. 3) suggests little surficial sediment mixing and uniform accumulation rate $\left(4.5 \mathrm{kgdry}_{\mathrm{wt} \mathrm{m}}{ }^{-2} \mathrm{yr}^{-1}\right.$, Table 2) since 1950. The effect of the surface mixed layer on core geochronology is to average sedimentary deposition events over a time scale of about 6 years. The integral sedimentary flux of excess ${ }^{210} \mathrm{~Pb}$ to this site (Table 2) is close to our expected $50 \mathrm{~Bq} \mathrm{~m}^{-2} \mathrm{yr}^{-1}$ based upon soil profile and rainfall collections in Townsville and Darwin. Bomb 

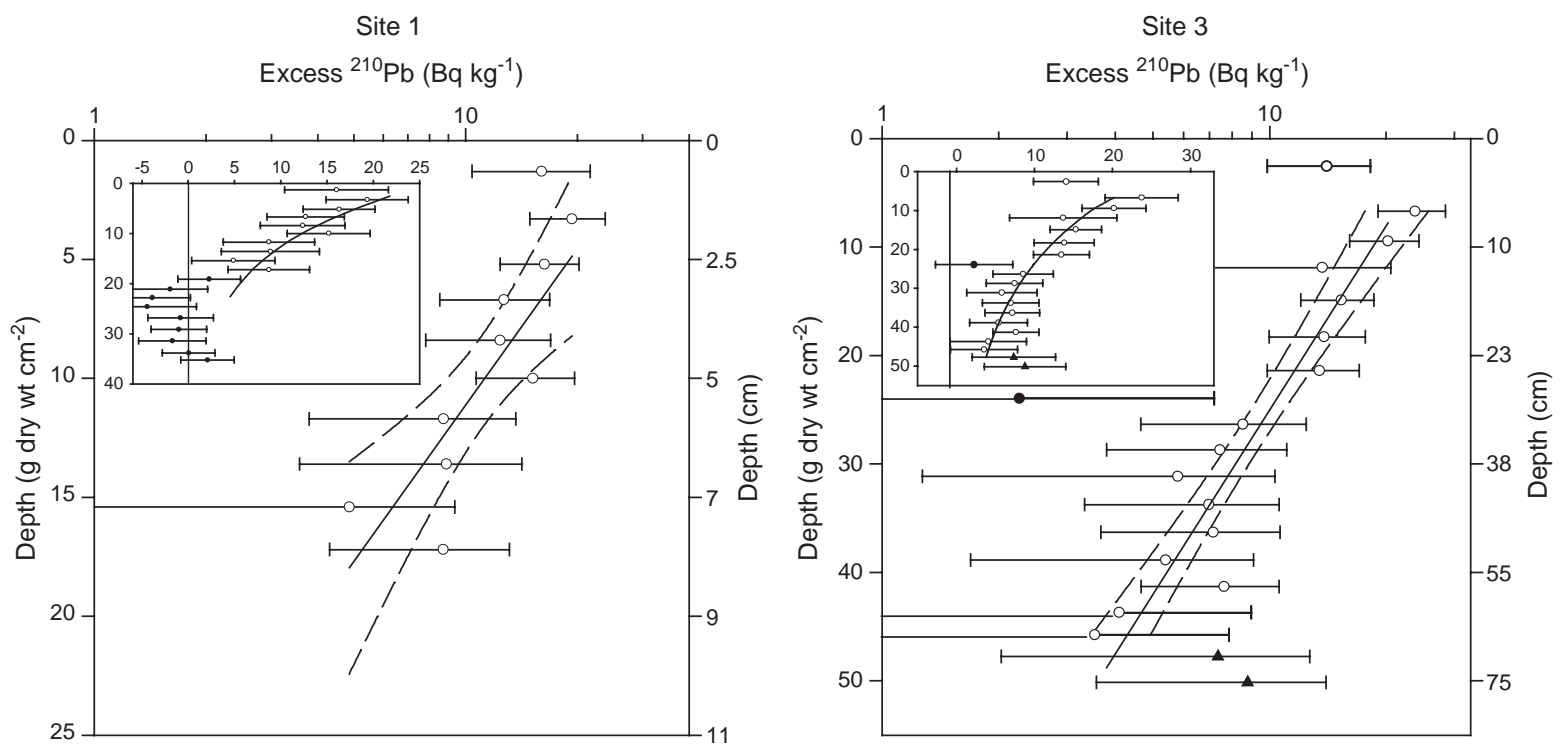

Fig. 3. Sediment core profiles, from sites 1 and 3, of excess ${ }^{210} \mathrm{~Pb}$ and sediment core depth, expressed in accumulated dry sediment weight per unit area $\left(\mathrm{g}\right.$ dry wt $\mathrm{cm}^{-2}$ ). The small insert figure shows a graph of the linear relation between excess ${ }^{210} \mathrm{~Pb}$ and accumulated sediment mass, which allows better representation of the low or zero activities of excess ${ }^{210} \mathrm{~Pb}$. The main graph shows the log of excess ${ }^{210} \mathrm{~Pb}$ plotted against accumulated sediment mass for the core. On the right axis we give core depth in $\mathrm{cm}$. Site 1 is near the Tipoeka River estuary, and site 3 is south of the Ajkwa River estuary main channel (see Fig. 1(b)). The error bars on the ${ }^{210} \mathrm{~Pb}$ data points are one standard deviation of the accumulated errors of calibration, weighing, and gamma counting. The open circles are excess ${ }^{210} \mathrm{~Pb}$, and the filled circles are excess ${ }^{210} \mathrm{~Pb}$ activities that are not significantly different from the activity of ${ }^{226} \mathrm{Ra}$. The bottom two slices (triangles) from site 3 are discussed in the results. The solid regression line is based upon the open circles only, and the dotted lines indicate $95 \%$ confidence limits on the regression. Our interpretation of sediment mass accumulation rate and the flux of excess ${ }^{210} \mathrm{~Pb}$ is given in Table 2.

Table 2

Sediment mass accumulation rate (MAR), from ${ }^{210} \mathrm{~Pb}$ profiles, the atmospheric supply rate of ${ }^{210} \mathrm{~Pb}$ in excess of parent ${ }^{226} \mathrm{Ra}$ necessary to maintain the sedimentary profile of excess ${ }^{210} \mathrm{~Pb}\left(\mathrm{Flux}{ }^{210} \mathrm{~Pb}\right)$ for the cores from the Ajkwa River estuary. We also give an estimate of MAR based upon the known history of mine waste production and excess copper concentrations in the cores (Fig. 2), where $\operatorname{MAR}(\mathrm{Cu})=\left[\mathrm{g}\right.$ dry wt $\mathrm{cm}^{-2}$ of core mass with excess $\left.\mathrm{Cu}\right] /[27$ years $]$

\begin{tabular}{lllll}
\hline Site & $\begin{array}{l}\text { MAR } \\
\mathrm{kg} \mathrm{dry} \mathrm{wt} \mathrm{m}^{-2} \mathrm{yr}^{-1}\end{array}$ & $\begin{array}{l}\text { Flux } \\
{ }^{210} \mathrm{~Pb} \mathrm{~Bq} \mathrm{~m}^{-2} \mathrm{yr}^{-1}\end{array}$ & $\begin{array}{l}\text { MAR }(\mathrm{Cu}) \\
\mathrm{kg} \mathrm{dry} \mathrm{wt} \mathrm{m}^{-2} \mathrm{yr}^{-1}\end{array}$ & Comments \\
\hline 1 & $4.5 \pm 1.2$ & 67 & 4.8 & \\
3 & $7.5 \pm 1.5$ & 167 & 9.3 & ${ }^{137} \mathrm{Cs}$ from $10 \mathrm{~g}$ dry wt cm ${ }^{-2}$ to bottom of core \\
4 & - & 86 & 13 & ${ }^{210} \mathrm{~Pb}$ profile incomplete, mixing of Cu downcore. \\
5 & - & 111 & Deeper mixing of excess Cu downcore \\
\hline
\end{tabular}

fallout ${ }^{137} \mathrm{Cs}$ was detected at very low activities to $10 \mathrm{~cm}$ core depth.

The major elements of the bulk sediment show little variation with depth in this core. Al concentrations increase with depth, from $1.5 \mathrm{mmol}$ at the core top to $2 \mathrm{mmol} \mathrm{g}^{-1}$ at the core bottom (Fig. 4(a)). Organic carbon (OC) concentrations are very high $\left(\sim 10 \mathrm{mmol} \mathrm{g}^{-1}\right)$ throughout this core (Table 3) and show little evidence of diagenetic consumption by aerobic or anaerobic processes, as the sulfur profile (Fig. 4(a)) shows little variation with depth. The ratio $\mathrm{OC} / \mathrm{N}(=38-50)$ varies little with depth, and indicates that the organic matter is of mangrove/terrestrial origin and of poor benthic 

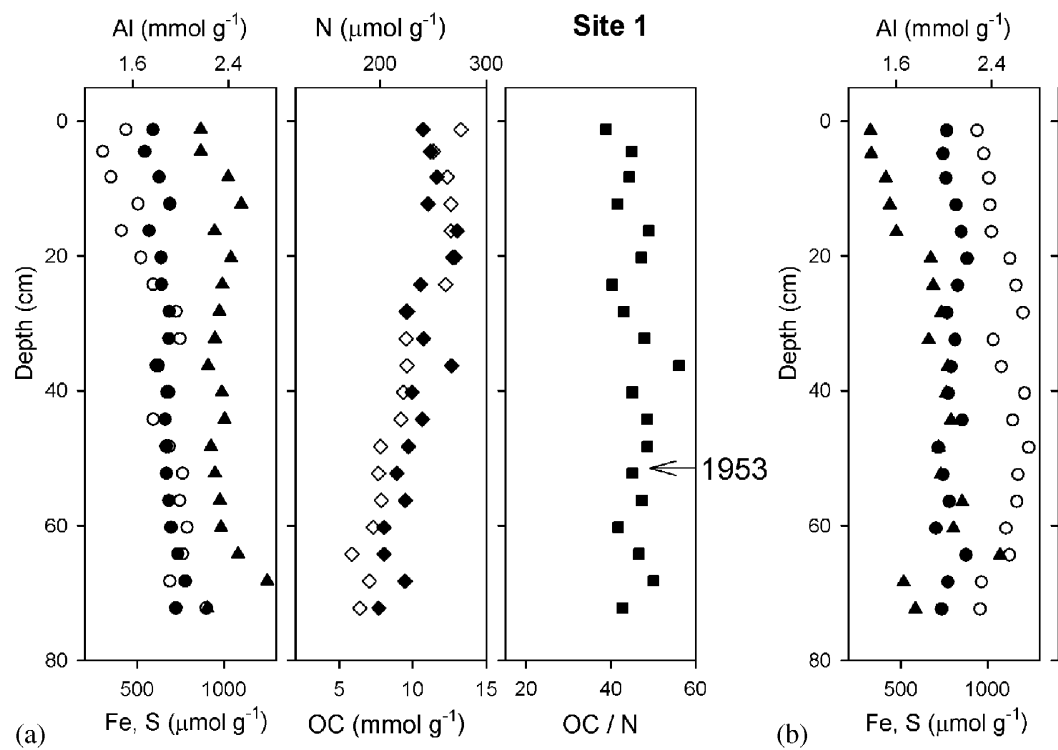

$\mathrm{N}\left(\mu \mathrm{mol} \mathrm{g} \mathrm{g}^{-1}\right)$

Site 3

(a)

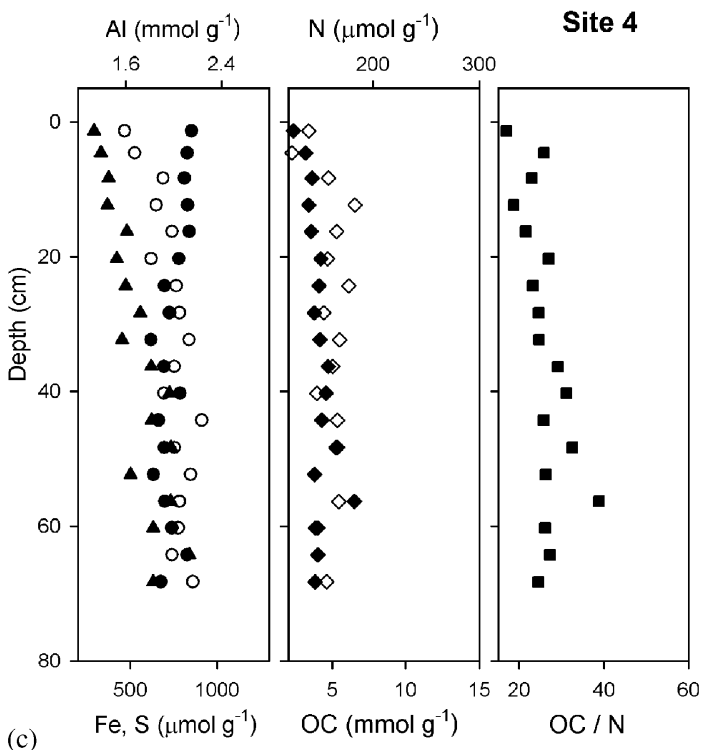

(b)
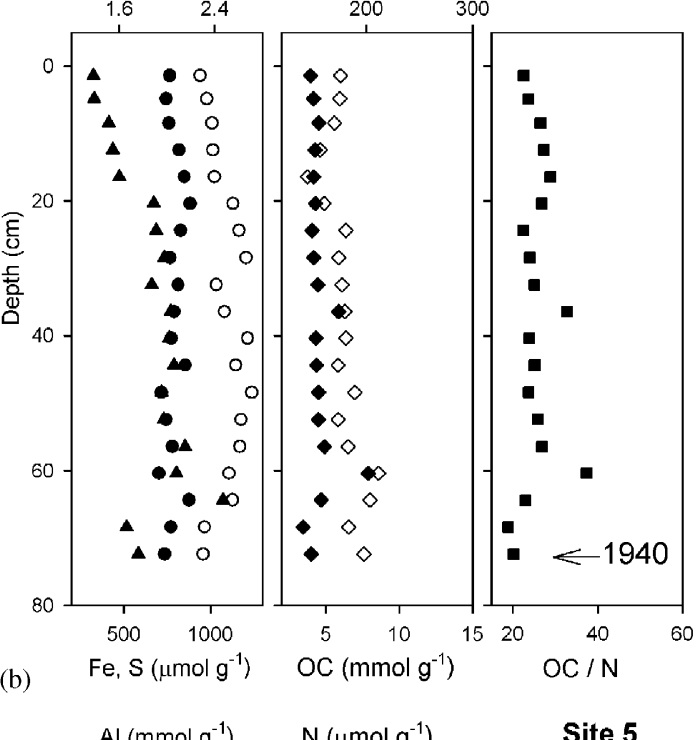

$\left.\mathrm{N}(\mu \mathrm{mol} \mathrm{g})^{-1}\right)$

Site 5
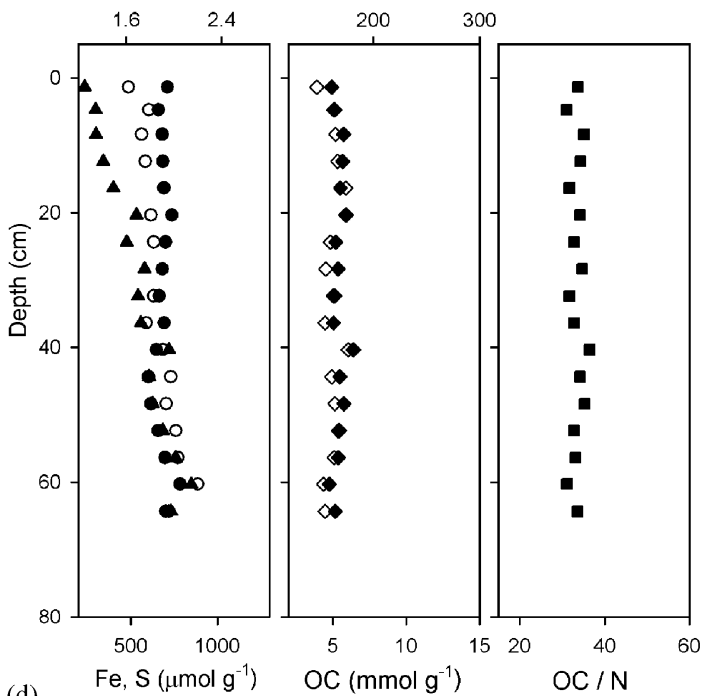

(d)

\begin{tabular}{llllll}
\hline$\circ \mathrm{Al}$ & $\diamond$ & $\mathrm{N}$ & $\mathrm{OC} / \mathrm{N}$ \\
$-\mathrm{Fe}$ & $\bullet$ & $\mathrm{OC}$ & & \\
$\bullet$ & $\mathrm{S}$ & & & & \\
\hline
\end{tabular}

Fig. 4. Variation of sediment concentration of aluminium $(\mathrm{Al})$, iron $(\mathrm{Fe})$, sulfur $(\mathrm{S})$, nitrogen $(\mathrm{N})$, organic carbon $(\mathrm{OC})$, and $\mathrm{OC} / \mathrm{N}$ for sediment cores from (a) site 1, (b) site 3, (c) site 4, and (d) site 5 (see Fig. 1(b)).

nutritional quality. Iron and sulfur vary little with depth in the sediment (Fig. 4(a)), and the excess of sulfur over iron suggests the presence of $\mathrm{FeS}$ and $\mathrm{FeS}_{2}$ minerals in abundance.
Amongst the trace elements, only copper shows large variations in concentration with sediment core depth. Concentrations of $\mathrm{Cu}$ in the pre-1960 section $(35-74 \mathrm{~cm})$ of the core (Fig. 2, Table 4) are 
Table 3

Concentrations of the major elements aluminium ( $\mathrm{Al})$, iron ( $\mathrm{Fe})$, sulfur $(\mathrm{S})$, organic carbon $(\mathrm{OC})$, and nitrogen $(\mathrm{N})$ in the sediment cores from the Ajkwa River estuary, Irian Jaya, Indonesia

\begin{tabular}{|c|c|c|c|c|c|c|c|c|c|c|}
\hline \multirow[t]{2}{*}{ Depth (cm) } & $\mathrm{Al}\left(\mathrm{mmol} \mathrm{g}^{-1}\right)$ & $\mathrm{Fe}\left(\mu \mathrm{mol} \mathrm{g}^{-1}\right)$ & $\mathrm{S}\left(\mu \mathrm{mol} \mathrm{g}{ }^{-1}\right)$ & $\mathrm{OC}\left(\mathrm{mmol} \mathrm{g}^{-1}\right)$ & $\mathrm{N}\left(\mu \mathrm{mol} \mathrm{g}^{-1}\right)$ & $\mathrm{Al}\left(\mathrm{mmol} \mathrm{g}^{-1}\right)$ & $\mathrm{Fe}\left(\mu \mathrm{molg}^{-1}\right)$ & $\mathrm{S}\left(\mu \mathrm{mol} \mathrm{g}^{-1}\right)$ & $\mathrm{OC}\left(\mathrm{mmol} \mathrm{g}^{-1}\right)$ & $\mathrm{N}\left(\mu \mathrm{mol} \mathrm{g}^{-1}\right)$ \\
\hline & \multicolumn{5}{|l|}{ Site 1} & \multicolumn{5}{|l|}{ Site 3} \\
\hline $0-2.5$ & 1.54 & 591 & 866 & 10.7 & 276 & 2.28 & 765 & 327 & 4 & 18 \\
\hline $2.5-6.5$ & 1.35 & 545 & 867 & 11.2 & 251 & 2.33 & 742 & 331 & 4.2 & 175 \\
\hline $6.5-10.5$ & 1.42 & 627 & 1025 & 11.6 & 263 & 2.38 & 759 & 413 & 4.5 & 170 \\
\hline $10.5-14.5$ & 1.64 & 688 & 1101 & 11.1 & 267 & 2.38 & 819 & 439 & 4.3 & 156 \\
\hline $14.5-18.5$ & 1.51 & 569 & 946 & 13 & 267 & 2.40 & 848 & 475 & 4.2 & 144 \\
\hline $18.5-22.5$ & 1.67 & 638 & 1041 & 12.7 & 271 & 2.55 & 883 & 672 & 4.3 & 160 \\
\hline $22.5-26.5$ & 1.77 & 641 & 991 & 10.5 & 262 & 2.60 & 829 & 685 & 4.1 & 181 \\
\hline $26.5-30.5$ & 1.96 & 685 & 972 & 9.7 & 225 & 2.66 & 765 & 733 & 4.2 & 174 \\
\hline $30.5-34.5$ & 2.00 & 683 & 949 & 10.7 & 225 & 2.41 & 813 & 663 & 4.4 & 177 \\
\hline $34.5-38.5$ & 1.80 & 623 & 908 & 12.6 & 226 & 2.48 & 789 & 769 & 5.9 & 180 \\
\hline $38.5-42.5$ & 1.89 & 683 & 986 & 10 & 222 & 2.68 & 774 & 761 & 4.3 & 181 \\
\hline $42.5-46.5$ & 1.77 & 662 & 1003 & 10.7 & 220 & 2.58 & 855 & 789 & 4.4 & 173 \\
\hline $46.5-50.5$ & 1.90 & 667 & 925 & 9.7 & 201 & 2.71 & 717 & 717 & 4.5 & 189 \\
\hline $50.5-54.5$ & 2.02 & 669 & 948 & 8.9 & 198 & 2.62 & 743 & 732 & 4.5 & 173 \\
\hline $54.5-58.5$ & 1.99 & 683 & 976 & 9.5 & 201 & 2.61 & 779 & 855 & 4.9 & 183 \\
\hline $58.5-62.5$ & 2.05 & 695 & 983 & 8.1 & 193 & 2.52 & 703 & 804 & 7.9 & 211 \\
\hline $62.5-66.5$ & 2.02 & 734 & 1083 & 8.1 & 173 & 2.55 & 876 & 1074 & 4.7 & 203 \\
\hline $66.5-70.5$ & 1.91 & 776 & 1251 & 9.5 & 190 & 2.31 & 771 & 516 & 3.5 & 183 \\
\hline $70.5-74.5$ & 2.22 & 724 & 902 & 7.7 & 181 & 2.30 & 734 & 584 & 4 & 198 \\
\hline \multicolumn{6}{|l|}{ Site 4} & \multicolumn{5}{|l|}{ Site 5} \\
\hline $0-2.5$ & 1.59 & 850 & 291 & 2.3 & 139 & 1.62 & 711 & 235 & 4.9 & 50 \\
\hline $2.5-6.5$ & 1.67 & 827 & 330 & 3.2 & 123 & 1.79 & 660 & 299 & 5.1 & 56 \\
\hline $6.5-10.5$ & 1.91 & 810 & 375 & 3.6 & 158 & 1.73 & 682 & 300 & 5.8 & 56 \\
\hline $10.5-14.5$ & 1.85 & 829 & 370 & 3.4 & 183 & 1.76 & 684 & 342 & 5.7 & 57 \\
\hline $14.5-18.5$ & 1.99 & 838 & 482 & 3.6 & 166 & 1.91 & 691 & 400 & 5.5 & 59 \\
\hline $18.5-22.5$ & 1.81 & 780 & 421 & 4.2 & 157 & 1.80 & 736 & 532 & 5.9 & 59 \\
\hline $22.5-26.5$ & 2.02 & 697 & 475 & 4.1 & 177 & 1.83 & 700 & 476 & 5.2 & 54 \\
\hline $26.5-30.5$ & 2.05 & 724 & 558 & 3.8 & 153 & 1.90 & 682 & 580 & 5.4 & 53 \\
\hline $30.5-34.5$ & 2.13 & 618 & 454 & 4.2 & 168 & 1.83 & 664 & 543 & 5.1 & 55 \\
\hline $34.5-38.5$ & 2.00 & 693 & 620 & 4.7 & 162 & 1.77 & 692 & 559 & 5 & 53 \\
\hline $38.5-42.5$ & 1.92 & 787 & 726 & 4.6 & 147 & 1.90 & 648 & 719 & 6.4 & 60 \\
\hline $42.5-46.5$ & 2.23 & 663 & 623 & 4.3 & 166 & 1.97 & 602 & 606 & 5.5 & 55 \\
\hline $46.5-50.5$ & 2.01 & 695 & 734 & 5.4 & 165 & 1.93 & 615 & 626 & 5.8 & 56 \\
\hline $50.5-54.5$ & 2.14 & 633 & 501 & 3.8 & 145 & 2.01 & 658 & 685 & 5.5 & 57 \\
\hline $54.5-58.5$ & 2.05 & 699 & 733 & 6.5 & 168 & 2.03 & 697 & 759 & 5.4 & 56 \\
\hline $58.5-62.5$ & 2.04 & 739 & 631 & 3.9 & 148 & 2.20 & 783 & 851 & 4.8 & 52 \\
\hline $62.5-66.5$ & 1.99 & 825 & 838 & 4 & 148 & 1.96 & 700 & 730 & 5.2 & 53 \\
\hline $66.5-70.5$ & 2.16 & 676 & 632 & 3.8 & 156 & & & & & \\
\hline
\end{tabular}

$1 \mu \mathrm{mol}=10^{-6} \mathrm{~mol}$, and $1 \mathrm{mmol}=10^{-3} \mathrm{~mol}$. To convert these data to $\mu \mathrm{g} \mathrm{g}^{-1}(\mathrm{ppm})$ or $\mathrm{mg} \mathrm{g}^{-1}$, multiply by the atomic mass of each element. 
Table 4

Concentrations of the trace elements copper $(\mathrm{Cu})$, zinc $(\mathrm{Zn})$, lead $(\mathrm{Pb})$, cadmium $(\mathrm{Cd})$, and mercury $(\mathrm{Hg})$ in sediment cores from the Ajkwa estuary, Irian Jaya, Indonesia

\begin{tabular}{|c|c|c|c|c|c|c|c|c|c|c|}
\hline \multirow[t]{2}{*}{ Depth cm } & $\mathrm{Cu}\left(\mu \mathrm{mol} \mathrm{g}{ }^{-1}\right)$ & $\mathrm{Zn}\left(\mathrm{nmol} \mathrm{g}^{-1}\right)$ & $\mathrm{Pb}\left(\mathrm{nmol} \mathrm{g}^{-1}\right)$ & $\mathrm{Cd}\left(\mathrm{pmolg}^{-1}\right)$ & $\mathrm{Hg}\left(\mathrm{pmolg}^{-1}\right)$ & $\mathrm{Cu}\left(\mu \mathrm{molg}^{-1}\right)$ & $\mathrm{Zn}\left(\mathrm{nmolg}^{-1}\right)$ & $\mathrm{Pb}\left(\mathrm{nmolg}^{-1}\right)$ & $\mathrm{Cd}\left(\mathrm{pmol} \mathrm{g}^{-1}\right)$ & $\mathrm{Hg}\left(\mathrm{pmolg}^{-1}\right)$ \\
\hline & \multicolumn{5}{|l|}{ Site 1} & \multicolumn{5}{|l|}{ Site 3} \\
\hline $0-2.5$ & 2.48 & 1162 & 113 & 1231 & 469 & 18.33 & 2388 & 197 & 1574 & 523 \\
\hline $6.5-10.5$ & 2.56 & 1234 & 110 & 1320 & 479 & 13.14 & 2290 & 184 & 1222 & 568 \\
\hline $10.5-14.5$ & 1.66 & 1121 & 104 & 1254 & 499 & 12.24 & 2434 & 211 & 1231 & 613 \\
\hline $14.5-18.5$ & 1.44 & 946 & 103 & 1014 & 513 & 8.42 & 2633 & 190 & 1351 & 733 \\
\hline $18.5-22.5$ & 0.61 & 914 & 101 & 1118 & 897 & 6.60 & 2337 & 196 & 1426 & 648 \\
\hline $22.5-26.5$ & 2.45 & 1230 & 110 & 1399 & 508 & 6.20 & 2246 & 158 & 1625 & 603 \\
\hline $26.5-30.5$ & 0.89 & 1079 & 87 & 1029 & 484 & 0.69 & 1343 & 124 & 1105 & 733 \\
\hline $30.5-34.5$ & 0.39 & 1003 & 91 & 953 & 489 & 8.83 & 1833 & 164 & 2246 & 573 \\
\hline $34.5-38.5$ & 0.46 & 910 & 83 & 780 & 543 & 2.54 & 1635 & 147 & 1134 & 683 \\
\hline $38.5-42.5$ & 0.41 & 956 & 88 & 886 & 523 & 2.45 & 1430 & 124 & 1059 & 673 \\
\hline $42.5-46.5$ & 0.42 & 932 & 78 & 922 & 573 & 2.81 & 1504 & 130 & 967 & 628 \\
\hline $46.5-50.5$ & 0.36 & 953 & 76 & 844 & 454 & 0.62 & 1233 & 104 & 867 & 643 \\
\hline $50.5-54.5$ & 0.51 & 998 & 86 & 1011 & 479 & 0.94 & 1309 & 120 & 819 & 658 \\
\hline $54.5-58.5$ & 0.34 & 956 & 67 & 779 & 459 & 0.52 & 1245 & 96 & 780 & 623 \\
\hline $58.5-62.5$ & 0.35 & 995 & 88 & 833 & 847 & 0.39 & 1239 & 91 & 1088 & 518 \\
\hline $62.5-66.5$ & 0.32 & 955 & 94 & 712 & 643 & 2.58 & 1660 & 142 & 1208 & 693 \\
\hline \multicolumn{6}{|l|}{ Site 4} & \multicolumn{5}{|l|}{ Site 5} \\
\hline $0-2.5$ & 15.70 & 2149 & 152 & 1651 & 389 & 11.66 & 1903 & 162 & 1198 & 528 \\
\hline $2.5-6.5$ & 12.48 & 2090 & 157 & 1162 & 459 & 7.92 & 1872 & 152 & 922 & 548 \\
\hline $6.5-10.5$ & 6.52 & 2047 & 154 & 1107 & 548 & 10.13 & 1895 & 163 & 1072 & 548 \\
\hline $10.5-14.5$ & 7.81 & 2163 & 152 & 1091 & 618 & 6.22 & 1924 & 152 & 965 & 484 \\
\hline $14.5-18.5$ & 7.26 & 2137 & 158 & 1204 & 499 & 3.74 & 1493 & 152 & 699 & 543 \\
\hline $18.5-22.5$ & 4.69 & 2024 & 141 & 1132 & 518 & 6.12 & 1831 & 150 & 912 & 573 \\
\hline $22.5-26.5$ & 3.44 & 1655 & 144 & 894 & 543 & 5.84 & 1741 & 153 & 940 & 538 \\
\hline $26.5-30.5$ & 3.82 & 1758 & 155 & 862 & 533 & 4.06 & 1620 & 127 & 807 & 528 \\
\hline $30.5-34.5$ & 1.60 & 1295 & 114 & 657 & 583 & 2.95 & 1469 & 134 & 917 & 548 \\
\hline 34.538 .5 & 2.31 & 1545 & 133 & 1639 & 528 & 3.64 & 1637 & 126 & 919 & 543 \\
\hline $38.5-42.5$ & 3.33 & 1727 & 128 & 931 & 563 & 0.69 & 1148 & 102 & 599 & 588 \\
\hline $42.5-46.5$ & 0.53 & 1020 & 102 & 452 & 583 & 0.56 & 1001 & 96 & 549 & 598 \\
\hline $46.5-50.5$ & 0.59 & 1101 & 114 & 585 & 553 & 0.38 & 1045 & 101 & 694 & 583 \\
\hline $50.5-54.5$ & 1.06 & 1236 & 115 & 575 & 553 & 0.41 & 1032 & 106 & 576 & 563 \\
\hline $54.5-58.5$ & 0.71 & 1232 & 115 & 1074 & 499 & 0.34 & 995 & 90 & 636 & 548 \\
\hline $58.5-62.5$ & 3.93 & 1709 & 141 & 920 & 563 & 0.61 & 1233 & 102 & 956 & 449 \\
\hline $62.5-66.5$ & 2.31 & 1416 & 117 & 933 & 538 & 2.67 & 1305 & 112 & 717 & 568 \\
\hline
\end{tabular}

$1 \mathrm{nmol}=10^{-9} \mathrm{~mol}$, and $1 \mathrm{pmol}=10^{-12} \mathrm{~mol}$. To convert these data to $\mathrm{ng} \mathrm{g}^{-1}$ or $_{\mathrm{pg} \mathrm{g}^{-1}}$, multiply these data by the atomic mass of each element. 
about $0.4 \mu \mathrm{mol} \mathrm{g}^{-1}$, and at a time horizon of about 1970 (22-26 cm core depth), $\mathrm{Cu}$ increases to $2.5 \mu \mathrm{mol} \mathrm{g}^{-1}$ at the core top, a factor of 6 increase. The accumulated sediment mass with excess copper above the $22-26 \mathrm{~cm}$ core horizon is $13 \mathrm{~g}$ dry wt $\mathrm{cm}^{-2}$ (Fig. 3) which can be divided by the 27 years of known mine tailings input (Fig. 2). This

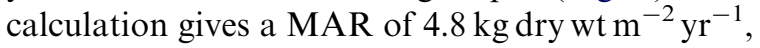
in good agreement with the MAR estimate from ${ }^{210} \mathrm{~Pb}$ profile regression. Zinc, lead, and cadmium also show a slight increase in concentration in the post-1970 section of the core $(0-35 \mathrm{~cm}$, Table 4$)$. There was no enhancement in mercury concentrations in the surface slices of this core (Table 4).

\subsection{Site 3}

At site 3 a core was obtained about $5 \mathrm{~km}$ upstream in a tidal creek south of the Ajkwa River estuary mouth, in Rhizophora mangrove forest (Fig. 1(b), Table 1). The sediment was an organic silty clay to $400 \mathrm{~cm}$ depth (described from longer cores collected for palynology), and the ${ }^{210} \mathrm{~Pb}$ profile (Fig. 3) indicates a tightly constrained mass accumulation rate of $7.5 \mathrm{~kg}$ dry wt $\mathrm{m}^{-2} \mathrm{yr}^{-1}$ with a sediment mixed layer thickness of $6 \mathrm{~cm}$. This depth of sediment mixing will average depositional events on an 11 year time scale, and the profile suggests uniform sediment accumulation for at least a century. The sedimentary inventory flux of ${ }^{210} \mathrm{~Pb}$ is approximately three times the expected input from the atmosphere (Table 2), suggesting considerable focussing of fine sediment from other regions of the estuary. Bomb fallout ${ }^{137} \mathrm{Cs}$ was detected in intermittent slices of this core. ${ }^{226} \mathrm{Ra}$ and ${ }^{40} \mathrm{~K}$ varied considerably in this core, with a maxima and minima that did not correspond with variations in the major host mineral elements (Al, Fe, OC).

The major element concentrations in this core indicate no major changes in bulk sediment composition (Table 3). Al concentrations are higher than in all other cores, with a decline from $2.6 \mathrm{mmol} \mathrm{Al} \mathrm{g}^{-1}$ at $25-50 \mathrm{~cm}$ depth to $2.3 \mathrm{mmol} \mathrm{g}^{-1}$ at the core top (Fig. 4(b)). Organic carbon and nitrogen vary little down the core length, and OC/ $\mathrm{N}$ ratios of $\sim 25$ indicate that the organic matter is of mangrove and terrestrial origin. $\mathrm{OC} / \mathrm{S}$ ratios rise from $\sim 5$ below $20 \mathrm{~cm}$ to over 10 at the core surface, suggesting a reduction in the supply rate of reduced sulfur beginning about 1975 or $\sim 30 \mathrm{~cm}$ depth (Fig. 4(b)), opposite to the trend of increasing sedimentary $\mathrm{Cu}$ (Fig. 2). Iron concentrations down the core are almost constant at $800 \mu \mathrm{mol} \mathrm{Fe} \mathrm{g}^{-1}$, but the sulfur profile shows a decline from $700 \mu \mathrm{molsg}^{-1}$ at $20-50 \mathrm{~cm}$ to $330 \mu \mathrm{mol} \mathrm{g}^{-1}$ at the sediment surface. $\mathrm{Fe} / \mathrm{S}$ ratios are $<1$ below $20 \mathrm{~cm}$ core depth (about 1975), but increase to over 2 at the core surface (Table 3 ).

The trace elements $\mathrm{Cu}, \mathrm{Zn}$, and $\mathrm{Pb}$ are enhanced in concentration in the surface $20 \mathrm{~cm}$ of this core. The bottom two slices appear to be contaminated by surface sediment $\mathrm{Cu}$, excess ${ }^{210} \mathrm{~Pb}$ and ${ }^{137} \mathrm{Cs}$, perhaps during core withdrawal or slicing in the field (Table 4, Fig. 3). Background $\mathrm{Cu}$ concentrations are probably $\sim 0.6 \mu \mathrm{mol} \mathrm{Cu} \mathrm{g}^{-1}$ for the entire region, but this core shows $\sim 2.5 \mu \mathrm{mol} \mathrm{Cu} \mathrm{g}^{-1}$ from $35-65 \mathrm{~cm}$ in the core. Beginning at $20 \mathrm{~cm}$ core depth there is a linear increase toward the surface sediment concentration of $18 \mu \mathrm{mol} \mathrm{Cu} \mathrm{g} \mathrm{g}^{-1}$. (Fig. 2). Calculations based on excess ${ }^{210} \mathrm{~Pb}$ MAR show that this increase in $\mathrm{Cu}$ concentration began in $1980 \pm 11$ years. The accumulated sediment mass with excess copper above the $30 \mathrm{~cm}$ horizon (Table 4) is

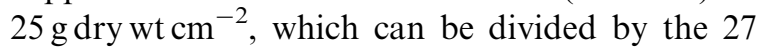
years of known mine tailings supply (Fig. 2). This calculation gives a MAR of $9.3 \mathrm{~kg}_{\mathrm{dry} \mathrm{wt} \mathrm{m}}{ }^{-2} \mathrm{yr}^{-1}$, a bit larger than the estimate from the ${ }^{210} \mathrm{~Pb}$ estimate. Background concentrations of $\mathrm{Zn}$ are slightly greater than $1 \mu \mathrm{mol} \mathrm{Zn} \mathrm{g}{ }^{-1}$ at $30-60 \mathrm{~cm}$ core depth, and surface sediments are enhanced by a factor of 2 (Table 4). Background $\mathrm{Pb}$ concentrations are slightly greater than $100 \mathrm{nmol} \mathrm{Pb} \mathrm{g}{ }^{-1}$ at 25-60 cm core depth, and surface sediments are enhanced by almost a factor of 2. Mercury fluctuates little $\left(500-700 \mathrm{pmol} \mathrm{Hg} \mathrm{g}^{-1}\right)$ down the core, but cadmium variations are larger (800-2200 pmol Cd g $\mathrm{g}^{-1}$ ) and do not show surface sediment enhancement (Table 4).

\subsection{Site 4}

The core from site 4 was obtained at the southern junction where an estuarine tidal creek meets the main mouth of the Ajkwa River estuary 

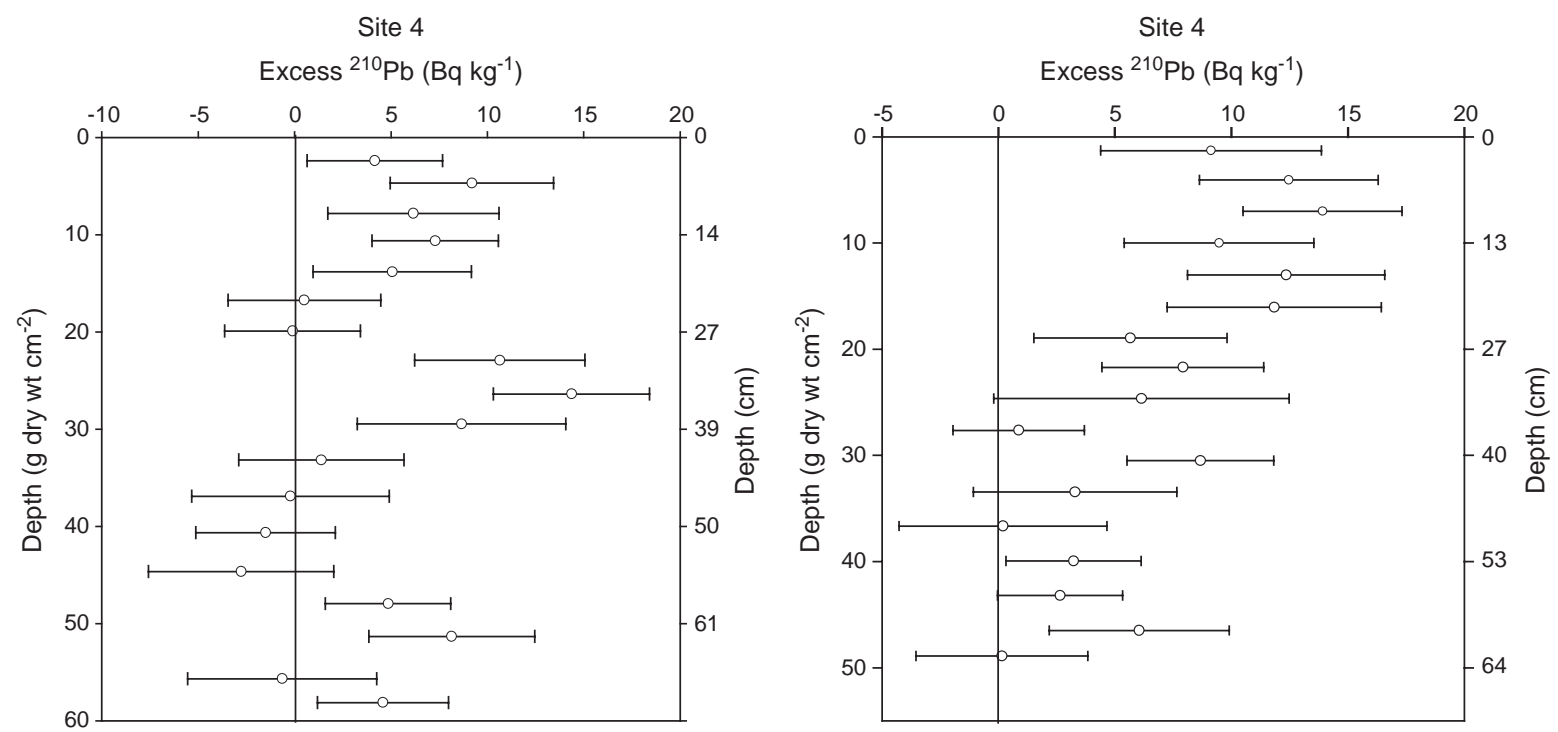

Fig. 5. Sediment core profiles, from sites 4 and 5 , of excess ${ }^{210} \mathrm{~Pb}$ and sediment core depth, expressed in accumulated dry sediment weight per unit area $\left(\mathrm{gdry} w \mathrm{~cm}^{-2}\right)$. On the right axis we give core depth in $\mathrm{cm}$. Sites 4 and 5 are near the Ajkwa River estuary main channel (see Fig. 1(b)). The error bars on the ${ }^{210} \mathrm{~Pb}$ data points are one standard deviation of the accumulated errors of calibration, weighing, and gamma counting. The open circles are excess ${ }^{210} \mathrm{~Pb}$, and the solid line indicates zero excess ${ }^{210} \mathrm{~Pb}$. Our interpretation of sediment mass accumulation rate and the flux of excess ${ }^{210} \mathrm{~Pb}$ is given in Table 2.

(Fig. 1(b), Table 1). The creek drains a Bruguiera dominated mangrove forest in the Ajkwa River estuary, in the pathway of the mine tailings. The sediment was a stiff silty clay to $200 \mathrm{~cm}$, and small excess ${ }^{210} \mathrm{~Pb}$ activities are found through-out the entire core (Fig. 5). Either the sediment is mixed to $60 \mathrm{~cm}$ depth, or there has been recent and rapid deposition of sediment with a similar and small excess ${ }^{210} \mathrm{~Pb}$ activity. Integral sedimentary annual flux of excess ${ }^{210} \mathrm{~Pb}$ is slightly greater than expected from direct rainfall (Table 2), however this is probably an underestimation as the core length did not capture all of the excess ${ }^{210} \mathrm{~Pb}$. Bomb fallout ${ }^{137} \mathrm{Cs}$ was detected in one core slice at $23 \mathrm{~cm}$.

The major element chemistry of this core indicates little change in bulk sediment composition over the time of deposition (Table 3). Al concentrations decline slightly from $2 \mathrm{mmol} \mathrm{Al} \mathrm{g}^{-1}$ at the core bottom to $1.6 \mathrm{mmol} \mathrm{g}^{-1}$ at the surface of the sediment core (Fig. 4(c)). Organic carbon and nitrogen vary little down the core, and $\mathrm{OC} / \mathrm{N}$ ratios of $\sim 23$ suggest a dominant source from terrestrial and mangrove forests, and little input from marine sources. Iron varies little down core (Fig. 4(c)), but there is a linear decline in $\mathrm{S}$ from core bottom concentrations of $800 \mu \mathrm{mol} \mathrm{Sg} \mathrm{S}^{-1}$ to surface core concentrations of $300 \mu \mathrm{molg}^{-1}$ (Fig. 4(c)). Fe/S ratio is about 1 in the bottom $30 \mathrm{~cm}$ of the core, but this ratio increases to 3 in the surface sediments (Table 3). This abrupt decline in sediment sulfur concentration toward the surface begins at the time horizon of increase in excess $\mathrm{Cu}(\sim 40 \mathrm{~cm})$.

The concentration of trace element $\mathrm{Cu}$ is enhanced in sediments above core depth $40 \mathrm{~cm}$ (Table 4). Background concentrations of $\mathrm{Cu}$ below $40 \mathrm{~cm}$ core depth are $\sim 0.6 \mu \mathrm{molCu} \mathrm{g}^{-1}$, and $\mathrm{Cu}$ increases in concentration above this depth in a linear fashion to $16 \mu \mathrm{molg}^{-1}$ (Fig. 2). There appears to be some deep mixing or diffusive flux of $\mathrm{Cu}$ to deeper horizon in this core. The accumulated sediment mass with excess copper above the $40 \mathrm{~cm}$ horizon (Table 4) is $35 \mathrm{~g}$ dry w $\mathrm{cm}^{-2}$, which can be divided by the 27 years of known mine tailings supply (Fig. 2). This calculation gives a MAR of $13 \mathrm{~kg} d r y ~ w t ~ m^{-2} \mathrm{yr}^{-1}$ (Table 2). $\mathrm{Zn}$ and $\mathrm{Pb}$ also have enhanced 
concentrations above $30 \mathrm{~cm}$ core depth, but the increase is only 1.5 to 2 fold (Table 4 ). $\mathrm{Hg}$ shows very little variation in concentration with depth at $\sim 500 \mathrm{pmol} \mathrm{Hg} \mathrm{g}^{-1}$, but Cd varies greatly from 500 to $1600 \mathrm{pmol} \mathrm{Cd} \mathrm{g}^{-1}$ (Table 4) throughout the core.

\subsection{Site 5}

The core at site 5 was collected half way up the tidal creek described in site 4 (Fig. 1(b), Table 1). The sediment was an organic silty clay to $195 \mathrm{~cm}$ depth, and the excess ${ }^{210} \mathrm{~Pb}$ profile indicates rapid sediment deposition and/or mixing to a depth of at least $36 \mathrm{~cm}$ (Fig. 5). The excess ${ }^{210} \mathrm{~Pb}$ profile in Fig. 5 for site 5 does not allow an estimation of MAR. The integral sedimentary flux of ${ }^{210} \mathrm{~Pb}$ to this site is approximately twice that expected from atmospheric supply (Table 2), and this suggests some focussing of fine sediment into the region of this core site. Bomb fallout ${ }^{137} \mathrm{Cs}$ was detected in the $28 \mathrm{~cm}$ slice only in this core.

The major element chemistry of this core indicates little change in bulk sediment composition over the time of deposition (Table 3). Aluminium declines from over $2 \mathrm{mmol} \mathrm{Alg}^{-1}$ at the core bottom to about $1.6 \mathrm{mmol} \mathrm{g}^{-1}$ at the core top (Fig. 4(d)). Organic carbon and nitrogen vary little, and the $\mathrm{OC} / \mathrm{N}$ ratio of 30 indicates a nitrogen-deficient, probably woody peat organic phase (Fig. 4(d)). Iron does not vary down the $65 \mathrm{~cm}$ core length, but sulfur declines linearly from $800 \mu \mathrm{mol} \mathrm{S} \mathrm{g}^{-1}$ at the core bottom to $230 \mu \mathrm{mol} \mathrm{g}^{-1}$ at the core top (Fig. 4(d), Table 3). Sulfur and iron are nearly equimolar at the core bottom, and the $>50 \%$ decline in $\mathrm{S}$ begins at the same core depth horizon as the increase in excess $\mathrm{Cu}$ (34-38 cm, see Table 4 and Fig. 2).

The concentrations of trace elements $\mathrm{Cu}, \mathrm{Zn}$, and $\mathrm{Pb}$ are enhanced in sediments deposited above $35 \mathrm{~cm}$ depth in this core. Background $\mathrm{Cu}$ concentrations in this core $(40-60 \mathrm{~cm})$ are about $0.6 \mu \mathrm{mol} \mathrm{Cu} \mathrm{g}{ }^{-1}$, and surface sediment concentrations are enhanced 20 fold to $12 \mu \mathrm{mol} \mathrm{Cug}^{-1}$ (Fig. 2). The accumulated sediment mass with excess copper above the

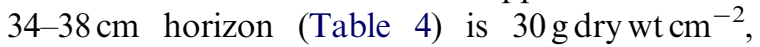
which can be divided by the 27 years of known mine tailings supply (Fig. 2). This calculation gives a

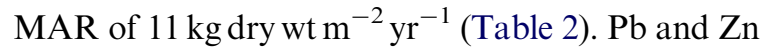
are similarly enhanced above $35 \mathrm{~cm}$ core depth, but only by a factor of 1.5 to 2 . $\mathrm{Cd}$ and $\mathrm{Hg}$ show little variation with core depth (Table 4).

\section{Discussion}

The flux of ${ }^{210} \mathrm{~Pb}$ to all of the core sites was slightly greater than expected from rainfall input $\left(\sim 50 \mathrm{~Bq} \mathrm{~m}^{-2} \mathrm{yr}^{-1}\right)$, indicating that mass accumulation estimation by the excess ${ }^{210} \mathrm{~Pb}$ method is feasible, and that these core locations are sites of recent sediment accumulation (Table 2). Low level activity of bomb fallout ${ }^{137} \mathrm{Cs}$, which was released into the atmosphere of the southern hemisphere mainly from 1960 to 1980 (Torgersen et al., 1983; EML, 2001), was present in all cores, but is not useful for core stratigraphy or geochronology. For core sites 1 and 3 , the core depositional time resolution is about 1 decade, and the core lengths containing excess ${ }^{210} \mathrm{~Pb}$ encompass the time period from approximately 1940 to the present. Cores from site 1 and 3 have the best ${ }^{210} \mathrm{~Pb}$ chronology, and can be used as evidence of little or no change in sediment accumulation rate over the time period of the core length.

The cores from site 4 and 5 can be interpreted to represent a sediment pile that has been deposited rapidly (over the last 20-30 years) from a sediment source that has been mixed and labelled with lower activities of excess ${ }^{210} \mathrm{~Pb}$ and infrequently with bomb fallout ${ }^{137} \mathrm{Cs}$. Surface sediment activities of excess ${ }^{210} \mathrm{~Pb}$ from sites 4 and 5 have been diluted to $50 \%$ of the surface activities of excess ${ }^{210} \mathrm{~Pb}$ in cores from sites 1 and 3 . This sediment source could be mine tailings mixed with resuspended mangrove sediment. However, there is a gradient of excess copper in the top half of these cores (Fig. 2), which argues against complete mixing. We use the concordance between mine waste production history and the sediment core copper profiles in Fig. 2 to estimate sediment mass accumulation rate (Table 2). MAR estimated from excess $\mathrm{Cu}$ in the core profiles is in agreement with the MAR estimated from ${ }^{210} \mathrm{~Pb}$ profiles for sites 1 and 3. MAR for sites affected by mine tailings supply are more than twice that of site 1 , which is 
furthest away from the influence of mine tailings discharge.

The mass accumulation rates estimated for all these cores are within the range of those found in the Gulf of Papua estuaries of the Purari, Kikori, and Fly River (Brunskill et al., 1995; Harris et al., 1993, 1996) and in tropical freshwater wetlands of New Guinea (Appleby and Oldfield, 1978; Oldfield et al., 1978, 1980; Hope et al., 1988). Accumulation rates are generally higher in locations close to the main pathway of the mine tailings through the estuary, but this is also the main pathway of natural suspended sediment transport in this region. Rapid estuarine sedimentation rates are to be expected in this region of great relief, precipitation, and tectonic activity (Milliman, 1995; Milliman and Syvitski, 1992; Milliman and Meade, 1983). Based upon experience in the Gulf of Papua, even greater mass accumulation rates of fine sediment (and tracer $\mathrm{Cu}$ ) would be expected along the inner shelf of the Arafura Sea offshore from this intertidal zone.

The major element geochemical data generally indicate little change in the bulk composition of the sediment over the length of the cores. Small declines in Al concentrations near the surface could be the result of increased supply rate of a silica rich phase, but we have no data to test this speculation. $\mathrm{Fe}$ concentration varies little $\left(600-800 \mu \mathrm{mol} \mathrm{Fe}^{-1}\right)$ in all of the cores, suggesting little movement of elements susceptible to porewater remobilization by low Eh reduction to more soluble species. All of the cores are rich in organic matter (3-10 $\mathrm{mmol} \mathrm{OC}^{-1}$ ) and show little evidence of change in supply rate or diagenetic decomposition of this woody, nitrogen-poor $\left(50-270 \mu \mathrm{mol} \mathrm{N} \mathrm{g}^{-1}\right)$ terrestrial and mangrove organic matter.

The mole ratio $\mathrm{OC} / \mathrm{S}$ is relatively constant at 10 for the site 1 core, but for main channel Ajkwa sites $3-5, \mathrm{OC} / \mathrm{S}$ generally varies from 5 to 6 at the core bottom to $10-25$ for the core surface sediments. Berner and Raiswell (1983) and Woolfe et al. (1995, and references therein) show that low $\mathrm{OC} / \mathrm{S}$ ratios (1-4) are characteristic of marine conditions, and ratios greater than 10 are associated with brackish to freshwater conditions. This is primarily related to observations that most $\mathrm{S}$ in sediments is $\mathrm{FeS}$ or $\mathrm{FeS}_{2}$ from microbial sulfate reduction, and seawater can supply much more sulfate than freshwater (Alongi, 1995). This reasoning suggests that sites 3-5 were exposed to more seawater pre-1950, and that there is now increased exposure to freshwater (low sulfate supply), or that microbial sulfate reduction rates have declined in the last 50 years. It is possible that enhanced copper concentrations in sediment porewater would decrease microbial decomposition reactions (Jonas, 1989). Wolanski et al. (1997) describes the physics of seawater and freshwater mixing in the Fly River estuary, where the residence time of freshwater in the estuary is approximately 3 weeks and this freshwater dispersal in the estuary is asymmetric. Changes in the main channels of freshwater dispersal through a delta or estuary can occur naturally, but in the case of the Ajkwa River estuary, the changes are probably due to the construction of levees to control the river channel flowpaths of mine tailings (Fig. 1(b)).

The Freeport Mine Ertsberg activities in the high mountains began in 1972, but large scale riverine delivery of tailings to the coastal estuaries from the Grasberg ore deposit began in the late 1980s (Mealey, 1996). Ore and overburden production rose from 18,059 tonne in 1990 to 189,434 tonne in 1995 (Fig. 2). Construction of levee banks on the Ajkwa River began in 1991 and is still being modified at present. This discharge of tailings from the Ajkwa Deposition Area is the source of the excess copper signal in the sediment cores discussed below.

$\mathrm{Cu}$, and to a lesser extent, $\mathrm{Zn}$ and $\mathrm{Pb}$, are enhanced in concentration in the top $20 \mathrm{~cm}$ of all cores. Background (pre-1950) $\mathrm{Cu}$ concentrations in core slices below $50 \mathrm{~cm}$ vary little $\left(0.3-0.6 \mu \mathrm{mol} \mathrm{Cu} \mathrm{g}^{-1}\right)$, and are similar to that found for the south coast of New Guinea (Gulf of Papua) and associated river estuaries (Alongi et al., 1991; Alongi et al., 1996). Cu concentrations increase in a linear fashion by factors of $7-5$ from $20 \mathrm{~cm}$ to the sediment surface, with the date of beginning of increased $\mathrm{Cu}$ supply being 1970 (Fig. 2), with an error of time estimation from ${ }^{210} \mathrm{~Pb}$ tracer models of about 1 decade for cores collected from sites 1 and 3 (Fig. 3). Copper rich 


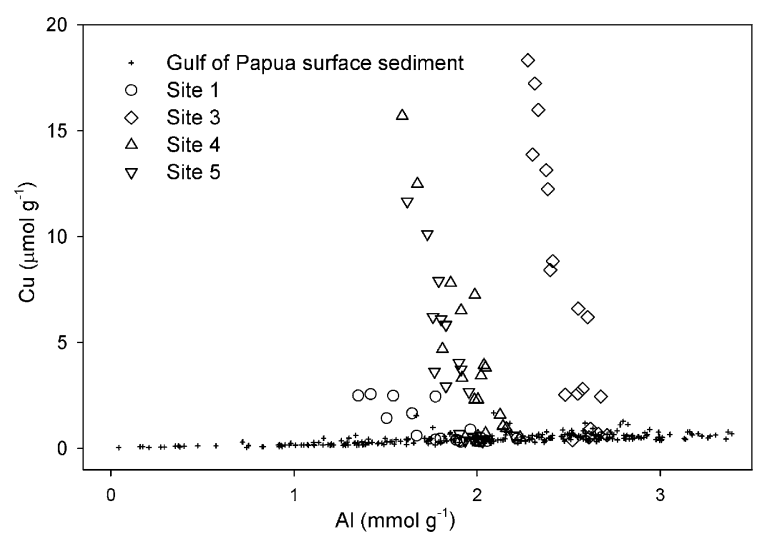

Fig. 6. The relationship between sedimentary $\mathrm{Cu}$ and $\mathrm{Al}$ concentrations in the Ajkwa River estuary sediment cores, and surface grab samples from the Gulf of Papua. Sediments from pre-1950 core slices in the Ajkwa River estuary cores fall within the $\mathrm{Cu}$ and $\mathrm{Al}$ relationship for the Gulf of Papua sediments. Ajkwa River estuary core slices from above $20 \mathrm{~cm}$ sediment depth are all greatly enriched in $\mathrm{Cu}$, relative to the expected $\mathrm{Cu}$ concentration in the host aluminosilicate mineral phase (Al).

tailings were probably mixed downward with natural pre-1970 sediments, especially at sites 3 and 4. In the Gulf of Papua estuaries and inner shelf, variations in natural sedimentary $\mathrm{Cu}$ concentration are closely related to $\mathrm{Al}$ (the proportion of terrestrial aluminosilicate weathering products as fine silt and clay) with an $\mathrm{Al} / \mathrm{Cu}$ ratio of 2000-5000 (Fig. 6). $\mathrm{Cu}$ concentrations in the surface $20 \mathrm{~cm}$ sediments of these Ajkwa River estuary cores do not vary in proportion to $\mathrm{Al}$, with $\mathrm{Al} / \mathrm{Cu}$ ratios of 100-130, indicating extreme $\mathrm{Cu}$ enrichment (Fig. 6). Background pre-1950 sediment (40-60 cm in these Ajkwa cores) has $\mathrm{Al} / \mathrm{Cu}$ in the range $4000-6000$ as expected.

The shape and gradient of the profile of $\mathrm{Cu}$ concentration is remarkably similar in all 4 cores, despite variations in mass accumulation rate and small major element composition differences. ${ }^{210} \mathrm{~Pb}$ profiles suggest that cores from sites 4 and 5 were rapidly deposited or totally mixed, yet the $\mathrm{Cu}$ profiles show a gradient of concentrations in the surface $25 \mathrm{~cm}$ of the deposit. Robbins (1986) illustrates how sedimentary geochemical gradients can be preserved in rapidly accumulating sedi- ments that show radiotracer evidence of sediment mixing. These $\mathrm{Cu}$ gradients through the sediment mixed layer could also be explained by a diffusionlike process, where dissolved $\mathrm{Cu}$-ligand, colloidal, and fine-particle $\mathrm{Cu}$-rich phases move into (and out of) the sediment in response to changes in dissolved and particulate $\mathrm{Cu}$ in the estuarine water (Skrabal et al., 1997), possibly related to mine tailings discharges over the last two decades. If this diffusion-like process behaved according to Fickian diffusion laws (Berner, 1971), we should observe an exponential decline in $\mathrm{Cu}$ with sediment depth. Our data do not show this (Fig. 2), but rather show a linear change with sediment depth. We interpret these core profiles of excess $\mathrm{Cu}$ to represent increased sediment supply rates from sediment sources with high copper concentrations.

Salomons and Eagle (1990) and Boyden et al. (1978) have shown that some metal concentrations are enhanced in proximity to copper mines in Papua New Guinea. Apte and Day (1998) and others have shown that nearly all marine "dissolved $\mathrm{Cu}$ " is probably complexed with dissolved organic matter and colloidal sized particles. Further research is needed to identify the host minerals for excess sedimentary $\mathrm{Cu}$, as the expected host phases (iron sulfide, organic matter, aluminosilicate clay) vary little down the core. This clear contaminant $\mathrm{Cu}$ signal is not masked by relatively high natural sedimentation rates in these cores, and confirms Morrison and Delaney's (1996) concern about the fate of mine tailings in this region.

Surficial sediment enhancement of $\mathrm{Zn}$ and $\mathrm{Pb}$ in these Ajkwa River estuary cores is much smaller (factor of 1.5-2 enrichment), but these small enhancements generally parallel the chronological variation of $\mathrm{Cu}$. $\mathrm{Zn}$ and $\mathrm{Pb}$ are usually highly correlated with $\mathrm{Al}$ in estuarine sediments, but $\mathrm{Al} /$ $\mathrm{Zn}$ and $\mathrm{Al} / \mathrm{Pb}$ ratios decline near the sediment surface, indicating enrichment in $\mathrm{Zn}$ and $\mathrm{Pb}$ relative to $\mathrm{Al}$. Background concentrations of $\mathrm{Zn}$ and $\mathrm{Pb}$ appear to be below $1 \mu \mathrm{mol} \mathrm{Zng}{ }^{-1}$ and $0.1 \mu \mathrm{mol} \mathrm{Pb} \mathrm{g}^{-1}$ in these cores.

An estimate of the change in rate of supply of $\mathrm{Cu}, \mathrm{Zn}$, and $\mathrm{Pb}$ to these core site sediments can be determined from the ${ }^{210} \mathrm{~Pb}$ and excess $\mathrm{Cu}$ mass accumulation rates (Table 2) and the elemental 
Table 5

Change in rate of supply of $\mathrm{Cu}, \mathrm{Pb}$, and $\mathrm{Zn}$ to sediments of core sites in the Ajkwa River estuary. Elemental deposition rate for sites 1 and 3 is calculated as the product of ${ }^{210} \mathrm{~Pb}$ derived accumulation rate (MAR) times the concentration of the element in pre-1950 sediment at the core bottom (Background), and in the top layers of the sediment core (Present). For sites 5 and 4, we used MAR calculated from the history of mine waste production (see Table 2)

\begin{tabular}{|c|c|c|c|c|c|}
\hline Site & $\begin{array}{l}\text { MAR } \\
\left(\text { kg dry wt m }{ }^{-2} \mathrm{yr}^{-1}\right)\end{array}$ & & $\begin{array}{l}\mathrm{Cu} \text { flux } \\
\left(\mathrm{mmolCu} \mathrm{m}{ }^{-2} \mathrm{yr}^{-1}\right)\end{array}$ & $\begin{array}{l}\text { Zn flux } \\
\left(\mathrm{mmol} \mathrm{Zn} \mathrm{m}^{-2} \mathrm{yr}^{-1}\right)\end{array}$ & $\begin{array}{l}\mathrm{Pb} \text { flux } \\
\left(\mathrm{mmol} \mathrm{Pb} \mathrm{m}^{-2} \mathrm{yr}^{-1}\right)\end{array}$ \\
\hline \multirow[t]{2}{*}{1} & \multirow[t]{2}{*}{4.5} & Background & 1.35 & 4.3 & 0.32 \\
\hline & & Present & 11.3 & 5.4 & 0.50 \\
\hline \multirow[t]{2}{*}{3} & \multirow[t]{2}{*}{7.5} & Background & 3.0 & 9.0 & 0.68 \\
\hline & & Present & 137 & 18 & 1.5 \\
\hline \multirow[t]{2}{*}{4} & \multirow[t]{2}{*}{13} & Background & 7.8 & 16 & 1.3 \\
\hline & & Present & 204 & 28 & 2.0 \\
\hline \multirow[t]{2}{*}{5} & \multirow[t]{2}{*}{11} & Background & 6.6 & 11 & 1.1 \\
\hline & & Present & 129 & 21 & 1.8 \\
\hline
\end{tabular}

composition of pre-1950 and post-1970 sediments (Table 5). The background pre-1950 supply rate of $\mathrm{Cu}$ to these sites was $1-3 \mathrm{mmol} \mathrm{Cum} \mathrm{mr}^{-2}$, and the present day supply rate has increased $10-45$ fold to $11-200 \mathrm{mmol} \mathrm{Cu} \mathrm{m}^{-2} \mathrm{yr}^{-1}$. Changes in the supply rate of $\mathrm{Zn}$ and $\mathrm{Pb}$ are less than 2 fold greater than background.

Core profiles of concentrations of $\mathrm{Cd}$ and $\mathrm{Hg}$ provide no evidence for changes in sediment depositional history for these sites. Apparent background concentrations of $\mathrm{Hg}$ vary between 400 and $800 \mathrm{pmol} \mathrm{Hg} \mathrm{g}^{-1}$, which is about 4-8 times higher than sediment core pre-1900 background concentrations in north Queensland estuarine sediments (Walker and Brunskill, 1997). Apparent background concentrations of Cd vary greatly $\left(500-1000 \mathrm{pmol} \mathrm{Cd} \mathrm{g}^{-1}\right)$ in these Ajkwa River estuary cores, and this is also 5-10 times greater than sediment core pre-1900 background concentrations in north Queensland estuaries (Tesiram, 1996).

\section{Conclusions}

Mass accumulation rates (MAR) at all the Ajkwa estuary sites are within the envelope of MARs measured in the Gulf of Papua and north Queensland estuaries.

Increasing values (toward the sediment surface) for the ratio of organic carbon/sulfur in these core profiles suggest a recent decline in microbial sulfate reduction rates. Copper inhibits many microbial community processes.

Copper concentrations are enhanced above pre1950 background in all of these core surficial sediments, with the largest enhancement of copper accumulation rate being over 40 -fold above background near the Ajkwa River estuary main channel.

Cadmium and mercury are not enriched in recent surface sediments of these cores, but the general background concentration is rather high, compared to the Gulf of Papua and north Queensland coastal sites.

\section{Acknowledgments}

Steve Boyle and Cassie Payn carried out measurements in the analytical lab. Peter Isdale is thanked for help with the business aspects of this work. This work was done on contract to P.T. Freeport Indonesia, with assistance from Howard Marsh of PTFI.

\section{References}

Alongi, D.M., Tirendi, F., Robertson, A.I., 1991. Vertical profiles of copper in sediments from the Fly Delta and Gulf of Papua (Papua New Guinea). Marine Pollution Bulletin 22, 253-255. 
Alongi, D.M., 1995. Decomposition and recycling of organic matter in muds of the Gulf of Papua, northern Coral Sea. Continental Shelf Research 15, 1319-1337.

Alongi, D.M., Boyle, S.G., Tirendi, F., Payn, C., 1996. Composition and behaviour of trace metals in post-oxic sediments of the Gulf of Papua, Papua New Guinea. Estuarine, Coastal and Shelf Science 42, 197-211.

Appleby, P.G., Oldfield, F., 1978. The calculation of lead-210 dates assuming a constant rate of supply of unsupported $\mathrm{Pb}-$ 210 to the sediment. Catena $5,1-8$.

Apte, S.C., Day, G.M., 1998. Dissolved metal concentrations in the Torres Strait and Gulf of Papua. Marine Pollution Bulletin 36, 298-304.

Berner, R.A., 1971. Principles of Chemical Sedimentology. McGraw-Hill, New York.

Berner, R.A., Raiswell, R., 1983. Burial of organic carbon and pyrite sulfur in sediments over Phanerozoic time: a new theory. Geochimica et Cosmochimica Acta 47, $855-862$.

Bonnyman, J., Molina-Ramos, J., 1971. Concentrations of lead-210 in rainwater in Australia during the years 1964-1970. Commonwealth of Australia, Department of Health, Technical Report CXRL/7.

Boyden, C.R., Brown, B.E., Lamb, K.P., Drucker, R.F., Tuft, S.J., 1978. Trace elements in the Upper Fly River, Papua New Guinea. Freshwater Biology 8, 189-205.

Brunskill, G.J., Woolfe, K.J., Zagorskis, I., 1995. Distribution of riverine sediment chemistry on the shelf, slope and rise of the Gulf of Papua. Geo-Marine Letters 15, $160-165$.

EML, 2001. Environmental Measurements Laboratory, US Department of Energy. http://www.eml.doe.gov/databases/

Harris, P.T., Baker, E.K., Cole, A.R., Short, S.A., 1993. Preliminary study of sedimentation in the tidally dominated Fly River Delta, Gulf of Papua. Continental Shelf Research 13, 441-472.

Harris, P.T., Pattiaratchi, C.B., Keene, J.B., Dalrymple, R.W., Gardner, J.V., Baker, E.K., Cole, A.R., Mitchell, D., Gibbs, P., Schroeder, W.W., 1996. Late Quaternary deltaic and carbonate sedimentation in the Gulf of Papua foreland basin: response to sea level change. Journal of Sedimentary Research 66, 801-819.

Hope, G., Gillieson, D., Head, J., 1988. A comparison of sedimentation and environmental change in New Guinea shallow lakes. Journal of Biogeography 15, 603-618.

Jonas, R.B., 1989. Acute copper and cupric ion toxicity in an estuarine microbial community. Applied and Environmental Microbiology 55, 43-49.

Li, Y.-H., Gregory, S., 1974. Diffusion of ions in seawater and in deep-sea sediments. Geochimica et Cosmochimica Acta 38, 703-714.

Loring, D.H., Rantala, R.T.T., 1992. Manual for the geochemical analyses of marine sediments and suspended matter. Earth-Science Reviews 32, 235-283.

Mealey, G.A., 1996. Grasberg. Published by FreeportMcMoRan Copper and Gold Inc., 1615 Poydras Street, New Orleans LA 70112. ISBN 0-9652890-0-1, 384pp.
Milliman, J.D., Meade, R.H., 1983. World-wide delivery of river sediment to the ocean. Journal of Geology 91, $1-21$.

Milliman, J.D., Syvitski, J.P.M., 1992. Geomorphic/tectonic control of sediment discharge to the ocean: the importance of small mountainous rivers. Journal of Geology 100, 525-544.

Milliman, J.D., 1995. Sediment discharge to the ocean from small mountainous rivers: the New Guinea example. GeoMarine Letters 15, 127-133.

Moroney, J. R., 1979. Radioactive fallout in the southern hemisphere from nuclear weapons tests. Australian Radiation Laboratory Publication ARL/TR013, ISSN 0157-1400, Lower Plenty Road, Yallambie, Victoria 3085, Australia.

Morrison, R.J., Delaney, J.R., 1996. Marine pollution in the Arafura and Timor Seas. Marine Pollution Bulletin 32, 327-334.

Oldfield, F., Appleby, P.G., Battarbee, R.W., 1978. Alternative ${ }^{210} \mathrm{~Pb}$ dating: results from the New Guinea Highlands and Lough Erne. Nature 271, 339-342.

Oldfield, F., Appleby, P.G., Thompson, R., 1980. Palaeoecological studies of lakes in the Highlands of Papua New Guinea. Journal of Ecology 68, 457-477.

Robbins, J.A., 1978. Geochemical and geophysical applications of radioactive lead. In: Nriagu, J.O. (Ed.), Biogeochemistry of Lead in the Environment, Elsevier Scientific Publishers, vol. 1A, pp. 285-393.

Robbins, J.A., 1986. A model for particle-selective transport of tracers in sediments with conveyor belt deposit feeders. Journal of Geophysical Research 96, 17081-17104.

Skrabal, S.A., Donat, J.R., Burdige, D.J., 1997. Fluxes of copper-complexing ligands from estuarine sediments. Limnology and Oceanography 42, 992-996.

Salomons, W., Eagle, A.M., 1990. Hydrology, sedimentology and the fate and distribution of copper in mine-related discharges in the Fly River system, Papua New Guinea. Science of the Total Environment 97/98, 315-334.

Tesiram, Y.A., 1996. The use of cadmium, uranium and arsenic as tracers of anthropogenic input into the Great Barrier Reef Lagoon. Honours Thesis, Department of Chemistry, James Cook University, Townsville, Queensland, Australia, $56 \mathrm{pp}$.

Torgersen, T., Chivas, A.R., Chapman, A., 1983. Chemical and isotopic characterization and sedimentation rates in Princess Charlotte Bay, Queensland. BMR Journal of Australian Geology and Geophysics 8, 191-200.

Walker, G.S., Ridd, M.J., Brunskill, G.J., 1996. A comparison of inductively coupled plasma atomic emission spectrometry and inductively coupled plasma mass spectrometry for determination of mercury in Great Barrier Reef sediments. Rapid Communications in Mass Spectrometry 10, 96-99.

Walker, G.S., Brunskill, G.J., 1997. A history of anthropogenic mercury input into the Great Barrier Reef Lagoon, Australia. Proceedings of the eighth International Coral Reef Symposium 2, 1889-1892.

Wasson, R. J. (ed.), 1992. Modern sedimentation and Late Quaternary evolution of the Magela Creek Plain. Research 
Report 6 of the Supervising Scientist for the Alligator Rivers Region, Commonwealth of Australia, Australian Government Publishing Service, Canberra, 322pp.

Wolanski, E., King, B., Galloway, D., 1997. Salinity intrusion in the Fly River estuary, Papua New Guinea. Journal of Coastal Research 13, 983-994.
Woolfe, K.J., Dale, P.J., Brunskill, G.J., 1995. Sedimentary C/S relationships in a large tropical estuary: evidence for refractory carbon inputs from mangroves. Geo-Marine Letters 15, 140-144. 